GRASAS Y ACEITES 67 (1)

January-March 2016, e118

ISSN-L: 0017-3495

doi: http://dx.doi.org/10.3989/gya.0369151

\title{
Physicochemical characterization and quality of cold-pressed peanut oil obtained from organically produced peanuts from Macedonian "Virginia" variety
}

\author{
S. Kostadinović Veličkovska ${ }^{\bowtie}$, S. Mitrev and Lj. Mihajlov \\ Faculty of Agriculture, University "Goce Delčev", Krste Misirkov bb, 2000 Štip, Macedonia \\ ${ }^{\square}$ Corresponding author: sanja.kostadinovik@ugd.edu.mk
}

Submitted: 15 March 2015; Accepted: 21 September 2015

\begin{abstract}
SUMMARY: The physicochemical characterization and quality of cold pressed peanut edible oil from the "Virginia" variety, organically produced from the region of Macedonia, were examined in this work for the first time. The fatty acid composition of the oil showed almost equal levels of oleic and linoleic acids with an abundance of $34.19 \pm 0.01$ and $36.13 \pm 0.01 \%$, respectively. The most dominant saturated fatty acid was palmitic acid with a level of $10.06 \pm 0.00 \%$. The level of tocopherols and other vitamin-E-related compounds was in strong agreement with the antioxidant activity of the oils measured by the DPPH assay. Almost equal amounts of $\alpha$ and $\gamma$ tocopherols indicated an antioxidant potential of $288.63 \pm 59.78 \mathrm{mg} \cdot \mathrm{L}^{-1} \alpha$-tocopherol. Phytosterols, as minor compounds present in the oils, can be additional antioxidants responsible for the health benefits of this oil in human nutrition. The four major pytosterols were $\beta$-sitosterol $\left(1812.21 \pm 22.17 \mathrm{mg} \cdot \mathrm{kg}^{-1}\right.$ oil), champesterol (320.55 $\pm 17.07 \mathrm{mg} \cdot \mathrm{kg}^{-1}$ oil), $\Delta 5$-avenasterol $\left(236.16 \pm 14.18 \mathrm{mg} \cdot \mathrm{kg}^{-1}\right)$ and stigmasterol $\left(133.12 \pm 12.51 \mathrm{mg} \cdot \mathrm{kg}^{-1}\right.$ oil). Induction time, Peroxide number, FFA and specific extinction ( $K_{232}$ and $K_{270}$, values 1.82 and 0.22$)$ gave us an indication of the oxidative stability of cold pressed peanut oil.
\end{abstract}

KEYWORDS: Cold pressed peanut oil; DPPH assay; Fatty acid profile; "Filla" oil; Pytosterols; Vitamin-E-active compounds

RESUMEN: Caracterización físico-química y calidad del aceite de cacahuete prensado en frío obtenido de nuez de Macedonia variedad "Virginia" producida orgánicamente. Se ha abordado por primera vez, en este trabajo, la caracterización físico-química y la calidad de aceite comestible de maní prensado en frío de la variedad "Virginia", de producción ecológica y procedente de la región de Macedonia La composición de ácidos grasos del aceite mostró casi los mismos niveles de los ácidos oleico y linoleico: $34,19 \pm 0,01$ y $36,13 \pm 0,01 \%$, respectivamente. El ácido graso saturado dominante fué el palmítico, 10,06 $\pm 0,00 \%$. El nivel de tocoferoles y otros compuestos relacionados con la vitamina-E estaba en estrecha relación con la actividad antioxidante de los aceites medidos mediante el ensayo de DPPH. Casi igual cantidad de $\alpha$ y $\gamma$ tocoferol indicó un potencial antioxidante de 288,63 $\pm 59,78 \mathrm{mg} \cdot \mathrm{L}^{-1}$ de $\alpha$-tocoferol. Los fitoesteroles, compuestos menores presentes en los aceites, pueden ser antioxidantes adicionales con beneficios para la salud y la nutrición humana. Los cuatro fitosteroles principales fueron $\beta$-sitosterol $\left(1812,21 \pm 22,17 \mathrm{mg} \cdot \mathrm{kg}^{-1}\right)$, campesterol $\left(320,55 \pm 17,07 \mathrm{mg} \cdot \mathrm{kg}^{-1}\right), \Delta 5$-avenasterol $\left(236,16 \pm 14,18 \mathrm{mg} \cdot \mathrm{kg}^{-1}\right)$ y estigmasterol $\left(133,12 \pm 12,51 \mathrm{mg} \cdot \mathrm{kg}^{-1}\right)$. El periodo de inducción, índice de peróxidos, FFA y extinción específica (K232 y K270 con valores de 1,82 y 0,22) nos indican la estabilidad oxidativa del aceite de cacahuete prensado en frío. 
PALABRAS CLAVE: Aceite de cacahuete; Ensayo DPPH; Fitosteroles; Perfil de ácidos grasos; Prensado en frí; Vitamina-E-activa

Citation/Cómo citar este artículo: Kostadinović Veličkovska S, Mitrev S, Mihajlov Lj. 2016. Physicochemical characterization and quality of cold-pressed peanut oil obtained from organically produced peanuts from Macedonian "Virginia" variety. Grasas Aceites 67 (1): e118. doi: http://dx.doi.org/10.3989/gya.0369151.

Copyright: (C) 2016 CSIC. This is an open-access article distributed under the terms of the Creative Commons Attribution-Non Commercial (by-nc) Spain 3.0 Licence.

\section{INTRODUCTION}

Current trends in the consumption of coldpressed edible oils, in particular, peanut oil make it necessary to research the quality, stability and nutritional impact on human health (Zock et al., 1995). The conventional processing of peanuts in the food industry involves mechanical pressing during which the temperature does not surpass $40^{\circ} \mathrm{C}$. This process yields cold-pressed peanut oil and low-value peanut cake. Peanut seeds are a good source of protein, lipids and fatty acids. Peanut seeds contain $45-50 \%$ oil (Grosso et al., 1999).

Cold pressed peanut oil enjoys a very popular place in human nutrition due to the high level of polyunsaturated fatty acids, tocopherols, pytosterols, carotenoids, chlorophylls and polyphenolics (Sullivan et al., 2011). A positive correlation between the consumption of polyphenol-enriched cold-pressed oil consumption and a reduced risk of coronary heart diseases, level of "LDL", degenerative diseases and cancer is well known (Varney et al., 2011).

Peanuts belong to the genus Arachis, a member of the family Leguminoseae, and are widely distributed in the tropics and moderate regions of the world. Peanuts make an important contribution to the diet in many countries. Peanut seeds are a good source of protein, lipid and fatty acids for human nutrition. The cold-pressed oil from peanuts is very important due to its significant level of $\alpha$ and $\gamma$-tocopherol, as well as significant amount of resveratrol. Trans-resveratrol or trans-3,5,40-trihidroxystilbene is the most abundant stilbene in peanuts and is responsible for the benefit to human health. The antioxidant and antimicrobial efficiency of resveratrol provides health benefits, such as the prevention of cardiovascular diseases, arteriosclerosis and cancer. Originally, epidemiological studies indicated an inverse relationship between food enriched with resveratrol and the risk of coronary heart disease (Kostadinović et al., 2012).

Many researchers have studied the chemical composition and nutritional value of cold-pressed peanut oil. Fatty acid and phytosterol compositions of peanut seeds have been studied by (Grosso et al., 1997). Grosso et al. studied the chemical composition of the oil of aboriginal peanut seeds from Uruguay (Grosso et al., 1999). Furthermore, Grosso et al. have reported the oil, protein, ash, carbohydrate contents, iodine value and fatty acid composition of some wild peanut specie (Arachis) seeds (Grosso et al., 2000). The level of phytosterols in different peanut species from the region of Bolivia and Argentina was the object of study in the work of Grosso et al. (1997). The effects of cultivar, location, and their interaction in the fatty acid composition have been investigated by Brown et al. (1975). In another study, fatty acid composition, protein levels, amino acid composition and other components have been investigated in peanut seeds (Ahmed and Young, 1982). Lopes et al. published a study for peanuts with an overview of the chemical composition, focusing on secondary metabolites and their biological activity (Lopes et al., 2011).

Peanuts are a rich source of oil $(45-50 \%)$. The oil obtained from the cold pressing of peanuts is pale yellow and has the characteristic "nutty" flavor of roasted peanuts. This characteristic flavor was examined by Chetschik et al. (2010). by application of stable isotope dilution analyses (SIDA) and gas chromatography-olfactometry. According to their findings, 26 odor-active compounds were identified and quantified in raw and pan-roasted peanut meal. 3-Isopropyl-2-methoxypyrazine, acetic acid, and 3-(methylthio) propanal showed the highest OAVs in raw peanuts, whereas methanethiol, 2,3-pentanedione, 3-(methylthio) propanal, and 2- and 3-methylbutanal as well as the intensely popcorn-like smelling 2-acetyl-1-pyrroline revealed the highest $\mathrm{OAV}$ in the pan-roasted peanut meal.

The fatty acid profile, vitamin-E-active compounds and phytosterol composition of peanut oil from South America was the object of study in the work of Carrín and Carelli. According to their finding, the most dominant fatty acids in peanut oil were palmitic (C16:0), oleic (C18:1) and linoleic (C18:2) acid. According to their findings, palmitic acid was present in the range from 9.3 to $13 \%$, oleic acid from 35.6 to $58.3 \%$ and linoleic acid from 20.9 to $43.2 \%$ (Carrín and Carelli, 2010). Regarding, the distribution of vitamin $\mathrm{E}$ active compounds, the most present were $\alpha$ and $\gamma$-tocopherol with levels between $18-57 \mathrm{mg} \cdot \mathrm{kg}^{-1}$ oil and $36-78 \mathrm{mg} \cdot \mathrm{kg}^{-1}$ oil, respectively. $\beta$ and $\delta$-tocopherol were not detected nor present in trace amounts till $6 \mathrm{mg} \cdot \mathrm{kg}^{-1}$ of oil (Carrín and Carelli, 2010).

It is obvious that there are already many published studies on the chemical composition of cold-pressed 
peanut oils, but, until now, to the best of our knowledge, there are no published results on the quality of the cold-pressed peanut oil from the region of Macedonia. The most famous variety of peanuts growing in the region of south-east Macedonia is the "Virginia" variety. The other two main varieties ("Ranner" type and "Valencia" type) are less present in the Macedonian region. The "Virginia" variety of peanuts has the largest kernels and accounts for most of the peanuts roasted in their shell. Therefore, the main object of this study was to give an overview of the chemical composition and general quality parameters including fatty acid profile, content of tocopherols and phytosterols as well as physicochemical evaluation, oxidative stability and antioxidant activity of cold-pressed peanut oil from the Macedonian "Virginia" variety.

\section{MATERIALS AND METHODS}

\subsection{Harvesting and selection of plant material}

The peanuts (Arachis hypogea, L.) were cultivated in the valleys of Strumica and Gevgelija regions with an average yield of $1200 \mathrm{~kg} \cdot \mathrm{ha}^{-1}$. The peanuts collected for the experimental purpose of this study belong to the "Virginia" variety.

The peanuts from the Macedonian "Virginia" variety were collected in mid-October from the valleys of Gevgelia and Strumica, 2012. The selected plant from Arachis hypogea, L., was hand-picked and dried for 7-10 days. After drying, the peanut seeds were separated from plant material and sorted according to their quality and maturity. Furthermore, additional dying at $40{ }^{\circ} \mathrm{C}$ was performed in drying ovens.

\subsection{Purification and cold pressing}

The purification process of the plant material started with the removal of broken or damaged peanuts. This step was necessary because unpurified plant material can negatively affect the quality of cold-pressed oil. After purification, the next step before pressing was peeling and roasting. After peeling, the peanuts were roasted at $120^{\circ} \mathrm{C}$ for $5 \mathrm{~min}$. The process of cold pressing was performed using a Komet single press (IBG Monforts Oecotec, Germany). After pressing, the fresh cloudy oil was purified from solid impurities in tanks by sedimentation over 17 days.

The quantities of plant material were collected only for the needs of this experiment and the yield of cold-pressed oil was lower than $1 \mathrm{~kg}$.

After sedimentation, the collected oil was filtrated by using a protection filter and bottled in dark $250 \mathrm{~mL}$ bottles. The cold pressed oil was stored at temperatures below $15^{\circ} \mathrm{C}$ in the dark.

\subsection{Analytical methods}

\subsubsection{Determination of the fatty acid composition}

The fatty acid composition of Macedonian coldpressed peanut oil was determined using gas chromatography equipped with a flame ionization detector (FID). The esters were prepared using 2 drops of each oil dissolved in $1 \mathrm{~mL}$ of heptane. After the addition of $50 \mu \mathrm{L}$ of sodium methylate with a concentration of $2 \mathrm{~mol} \cdot \mathrm{L}^{-1}$, the samples were homogenized. After homogenization, $100 \mu \mathrm{L}$ of distilled water were added to each sample. Samples were centrifuged and the lower phase was removed: while $50 \mu \mathrm{L}$ of $1 \mathrm{M} \mathrm{HCl}$ were added to the upper phase. After a second homogenization, sodium sulphate anhydride was added to remove water traces. Finally, the upper phase was transferred to GC vials and fatty acid methyl esters were analyzed using a capillary GC equipped with a CP7420 Select FAME column, $100 \mathrm{~m} \times 0.25 \mathrm{~mm}$ internal diameter with $0.25 \mu \mathrm{m}$ film thickness. The analyses were performed on an Agilent 6890 equipped with KAS4Plus and FID. The oven temperature was programmed to increase from $150{ }^{\circ} \mathrm{C}$ to $240^{\circ} \mathrm{C}$ at a rate of $1.5^{\circ} \mathrm{C} \cdot \mathrm{min}^{-1}$ with the isotherm kept at $240^{\circ} \mathrm{C}$ for $20 \mathrm{~min}$. The injector and detector temperature were both $260{ }^{\circ} \mathrm{C}$. Hydrogen was used as the carrier gas at an average velocity of $25 \mathrm{~mL} \cdot \mathrm{min}^{-1}$. The retention times of separated peaks were confirmed by FAME standards.

\subsubsection{Determination of tocopherols}

$100 \mathrm{mg}$ of cold pressed peanut oil were dissolved in $1 \mathrm{~mL}$ of heptane. The determination of tocopherols was performed with an HPLC instrument equipped with an L6000 pump, a Merck-Hitachi F-1000 fluorescence detector with excitation wavelength on $295 \mathrm{~nm}$ and emission wavelength of $330 \mathrm{~nm}$ and a Diol phase HPLC column $25 \mathrm{~cm} \times 4.6 \mathrm{~mm}$ ID (Merck, Darmstadt, Germany). The flow rate was $1.3 \mathrm{~mL} \cdot \mathrm{min}^{-1}$ and the injection volume $20 \mu \mathrm{L}$. The mobile phase was a mixture of heptane and TBME at a ratio 95:5.

\subsubsection{Rancimat test}

For the determination of the oxidative stability of Macedonian peanut oil, a Metrohm Rancimat model 743 (Herisau, Switzerland) was used. In order to determine the oil stability index (OSI), a stream of purified air was passed through $3.6 \mathrm{~g}$ of oil at $120^{\circ} \mathrm{C}$ at a flow rate of $20 \mathrm{~L} \cdot \mathrm{h}^{-1}$. For each sample of oil, the OSI index was determined in two portions by measuring two samples in the apparatus simultaneously. The induction time in hours was automatically recorded and taken as the break point of the plotted curves (the intersection point of the two extrapolated parts of the curve). 


\subsubsection{Peroxide value}

For the determination of peroxide value, the DGF standard method C-VI 6a - Part 1 (05) according to Wheeler was used. In brief, for titration of the oil, a standard solution of sodium thiosulfate was prepared with a concentration of $0.01 \mathrm{~mol} \cdot \mathrm{L}^{-1}$. A mixture of glacial acetic acid and isooctane was prepared in the ratio of 60:40 and was used as extracting agent for the oils. A saturated solution of potassium iodide was prepared by dissolving $10 \mathrm{~g}$ potassium iodide in $5 \mathrm{~mL}$ of boiled Millipore water. Analyses were performed by dissolving of $5.0 \mathrm{~g}$ of oil in $50 \mathrm{~mL}$ of extracting agent and $100 \mathrm{ml}$ of Millipore water. After adding $500 \mu \mathrm{L}$ of the saturated solution of potassium iodide, the potentiometric titration was performed by using the automatic titrator, Methrom 888 Titrando (Methrom, Herisau, Switzerland).

\subsubsection{Determination of free fatty acid content (Acidity)}

For determination of the content of free fatty acids the DGF standard method C-V 2 (06) was used. In brief, a mixture of ethanol and light petroleum was prepared in the ratio of 50:50 and was used as extracting agent for the oil. $10.0 \mathrm{~g}$ of oil was dissolved in this mixture and titration was performed using potassium hydroxide at a concentration of $0.1 \mathrm{~mol} \cdot \mathrm{L}^{-1}$. Potentiometric titration was performed using the automatic titrator, Methrom 888 Titrando (Methrom, Herisau, Switzerland).

\subsubsection{Determination of ultraviolet absorbance expressed as specific $U V$ extinction}

This method was equivalent to ISO 3656:2012. For this purpose, $1.0 \mathrm{~g}$ of oil was dissolved into a $100-\mathrm{mL}$ flask by iso-octane. The mixture was shaken and the solution was transferred into rectangular quartz cells with covers, having an optical length of $1 \mathrm{~cm}$ and determinations were made at 232 and $268 \mathrm{~nm}$. The absorption at the wavelengths specified in the method is due to the presence of conjugated diene and triene in the oil.

\subsubsection{Determination of phytosterols}

The sterol composition of the cold-pressed peanut oil was determined following ISO/FIDS 12228:1999 (E). In brief, $250 \mathrm{mg}$ of oil were saponified with a solution of ethanolic potassium hydroxide by boiling under reflux. The unsaponifiable matter was isolated by solid-phase extraction on an aluminium oxide column (Merck, Darmstadt, Germany) onto which fatty acid anions were retained and sterols passed through. The sterol fraction was separated from other unsaponifiable matter by thin-layer chromatography (Merck, Darmstadt, Germany), re-extracted from the
TLC material, and afterwards, the composition of the sterol fraction was determined by GLC using betulin as internal standard. The compounds were separated on an SE 54 CB (50 m long, $0.32 \mathrm{~mm} \mathrm{ID,} 0.25 \mu \mathrm{m}$ film thickness) (Macherey-Nagel, Düren, Germany). Further parameters were as follows: hydrogen as carrier gas, split ratio 1:20, injection and detection temperature adjusted to $320{ }^{\circ} \mathrm{C}$, temperature program, $245^{\circ} \mathrm{C}$ to $260{ }^{\circ} \mathrm{C}$ at $5^{\circ} \mathrm{C} \cdot \mathrm{min}^{-1}$. Peaks were identified either by standard compounds ( $\beta$-sitosterol, campesterol, stigmasterol), by a mixture of sterols isolated from rape seed oil (brassicasterol) or by a mixture of sterols isolated from sunflower oil ( $\Delta 7$-avenasterol, $\Delta 7$-stigmasterol, and $\Delta 7$-campesterol). All other sterols were firstly identified by GC-MS and afterward analyzed by comparison of retention times.

\subsubsection{Determination of antioxidant activity by DPPH assay}

The antioxidant activity of cold-pressed peanut oil was estimated spectro-photometrically using the DPPH assay.

For this purpose, the antioxidant activity of the oil was expressed as percentage of de-colorization of a solution of the stable radical DPPH (2,2-diphenyl-1-picrylhydrazyl radical) at $517 \mathrm{~nm}$. The DPPH reagent was dissolved in hexane and the stock solution of $0.25 \mathrm{~mL}$ with a concentration of $0.5 \mathrm{M}$ was used for the determination of the antioxidant activity. $\alpha$-tocopherol at different concentrations $\left(100-1000 \mathrm{mg} \cdot \mathrm{L}^{-1}\right)$ was dissolved in hexane and used as standard for the preparation of the calibration curve.

\subsubsection{Statistical analyses}

A one-way ANOVA was used to examine the level of every particular minor and major compound by considering the type of oil. The significance level of all statistical analyses was set at 0.05 . The level of significance of difference between the percentages of fatty acids, level of tocopherols, level of phytosterols, and values of antioxidant activity measured by the DPPH assay mean values was determined at $5 \%$ by a one-way ANOVA using Tukey's test. This treatment was carried out using SPSS v.16.0 software, IBM Corporation, USA.

\section{RESULTS AND DISCUSSION}

\subsection{Fatty acid composition}

Fatty acids are very important to human nutrition and in vegetable oils they are manly presented as triacylglycerols (TAG). Furthermore, they are classified as saturated, monounsaturated (MUFA) and polyunsaturated fatty acid (PUFA). The unsaturated fatty acids are classified into well-known series, such 
as omega-9, omega-6 and omega-3. Omega-9 fatty acids are considered as non-essential for the human diet and omega- 6 and omega- 3 are essential since these fatty acids cannot be synthetized by mammals and they must be obtained from the diet.

The fatty acid composition of the cold pressed peanut oil from the "Virginia" variety is presented in Table 1. Regarding saturated fatty acids, the coldpressed oil from peanuts had the highest percentage of palmitic acid $(10.06 \pm 0.00 \%)$. Stearic acid was presented in significantly lower levels $(4.40 \pm 0.01 \%)$. Oleic acid and linoleic acids as unsaturated fatty acids were the most dominant with levels of $34.19 \pm 0.01$ and $36.13 \pm 0.01 \%$, respectively. Lignoceric acid was abundant at a level of $3.93 \pm 0.00 \%$. Paullinic (Omega -7) fatty acid was detected at the level of $1.37 \pm 0.00 \%$ in the sample of peanut oil organically produced from the territory of Macedonia. The fatty acid profile was in good agreement with data published by Özcan and Seven who stated that palmitic and stearic acids were the most abundant saturated fatty acids in a Turkish variety of peanut oils (in the range of $8.70 \%$ to $13.03 \%$ for palmitic acid and $3.77 \%$ to $4.53 \%$ for stearic acid) (Ozcan and Seven, 2003). However, Carrín and Carelli (2010) stated that the degree of saturation in peanuts oil is dependent on temperature, genotype, seed maturity, and growth location as well as the interaction of all these factors. More precisely, seed development in regions

TABLE 1. Fatty acid composition of cold-pressed peanut oil (\%). Fatty acid analyses were performed in duplicate and the variation between duplicates was less than $1 \%$

\begin{tabular}{|c|c|}
\hline Fatty acids & $(\%)$ \\
\hline $\mathrm{C} 16: 0$ & $10.06 \pm 0.00^{b}$ \\
\hline C18:0 & $4.40 \pm 0.01^{\mathrm{c}}$ \\
\hline C18:1, trans 1 & $0.51 \pm 0.00^{\mathrm{e}}$ \\
\hline C18:1, trans 2 & $0.25 \pm 0.00^{\mathrm{e}}$ \\
\hline $\mathrm{C} 18: 1$, trans 3 & $0.16 \pm 0.01^{\mathrm{e}}$ \\
\hline C18:1 D9 & $34.19 \pm 0.01^{\mathrm{a}}$ \\
\hline C18:1 D11 & $0.57 \pm 0.01^{\mathrm{e}}$ \\
\hline C18:2 & $36.13 \pm 0.01^{\mathrm{a}}$ \\
\hline C18:3 & $0.33 \pm 0.00^{\mathrm{e}}$ \\
\hline C20:0 & $0.10 \pm 0.00^{\mathrm{e}}$ \\
\hline C20:1 & $1.37 \pm 0.00^{d}$ \\
\hline $\mathrm{C} 20: 2,11,14$ & $0.16 \pm 0.00^{\mathrm{e}}$ \\
\hline $\mathrm{C} 24: 0$ & $3.93 \pm 0.00^{c}$ \\
\hline SFA & $18.49 \pm 0.01$ \\
\hline MUFA & $37.05 \pm 0.03$ \\
\hline PUFA & $36.62 \pm 0.01$ \\
\hline Total & $92.16 \pm 0.05$ \\
\hline
\end{tabular}

GC analyses were performed in duplicate. The different letters mean significant differences $(p<0.05)$ among results. The letters are $\mathrm{a}, \mathrm{b}, \mathrm{c}, \mathrm{d}$ and e according to the decrease in the result values. with lower temperatures usually produces oil with higher levels of unsaturated fatty acid. According to the results published by Carrín and Carelli (2010), Macedonian peanut oil belongs to the relatively high linoleic acid oil category $(36.13 \%)$. As can be seen from table 1, the highest abundance with a percentage of $37.05 \pm 0.03 \%$ was attributed to monounsaturated fatty acids (MUFA). Oleic acid was the most dominant monounsaturated fatty acid. Furthermore, polyunsaturated fatty acid (PUFA) was present at the level of $36.62 \pm 0.01 \%$ with linoleic acid as the most dominant fatty acid. Finally, the lowest percentage belonged to saturated fatty acids (SFA) with $18.49 \pm 0.01 \%$ of the total fatty acid composition. The total fatty acids dominated $92 \%$ whereas the rest belonged to traces below $0.05 \%$ each.

\subsection{Oxidative stability}

Regarding the results from Table 2, the coldpressed peanut oil from Macedonian "Virginia" variety had a very good oxidative stability index (OSI) of $6.3 \pm 0.3 \mathrm{~h}$ which corresponded to over $18 \%$ of saturated fatty acids in this oil. Furthermore, the relatively high oxidative stability of this oil can be explained by the high content of monounsaturated oleic acid with an abundance of $34.19 \%$. On the other hand, the remarkable stability of this oil can be explained by the Maillard Reaction Products (MRPs) formed during roasting, which are products of the reactions among reducing sugars and amino acids at elevated temperatures and low moisture. Durmaz et al. (2010) explained that the MRPs obtained from model systems could also retard the oxidative deterioration of oils. According to their findings, during the process of roasting apricot kernel seeds, the degradation of naturally occurring antioxidants and formation of antioxidant MRPs occured together. Under severe roasting conditions, the degradation rate might have been higher than the formation of MRPs and the total antioxidant capacity could be reduced. According to the findings of O' Keefe et al., high oleic peanut oils with $75.6 \%$ oleic acid had better oxidative stability than normal oil (O' Keefe et al., 1993). Almost equal amounts of oleic and linoleic acid and a significant amount of Vitamin-E-active compounds resulted in oxidative stability for over $6 \mathrm{~h}$.

\subsection{Peroxide value, free fatty acids (acidity) and specific extinction}

Peroxide value and specific extinction at $232 \mathrm{~nm}$ summarize the oxidative state, while the amount of free fatty acids reveals some information about the quality of the raw material used. The content of free fatty acids in Macedonian peanut oil was significantly below the limit defined for cold-pressed and Virgin oils by the Codex Standard for Named Vegetable Oils as $2.0 \%$. This was an indication of 
TABLE 2. Oil stability index (OSI) from the Rancimat test, peroxide number, free fatty acids (FFA), specific extinction and DPPH assay

\begin{tabular}{|c|c|c|c|c|c|c|}
\hline \multirow[b]{2}{*}{$\begin{array}{l}\text { Cold-pressed } \\
\text { peanut oil }\end{array}$} & \multirow[b]{2}{*}{$\begin{array}{l}\text { Induction time } \\
\text { at } 120^{\circ} \mathrm{C} \text { (h) }\end{array}$} & \multirow[b]{2}{*}{$\begin{array}{l}\text { Peroxide number } \\
\text { (meq } \mathbf{O}_{2} \cdot \mathbf{k g}^{-1} \text { oil) }\end{array}$} & \multirow[b]{2}{*}{$\begin{array}{l}\text { FFA } \\
(\%)\end{array}$} & \multicolumn{2}{|c|}{ Specific extinction } & \multirow{2}{*}{$\begin{array}{l}\text { Consumption of DPPH after } \\
15 \mathrm{~min} \text {. at } 517 \mathrm{~nm} \text { (equivalent } \\
\text { as } \mathrm{mg} \cdot \mathrm{L}^{-1} \alpha \text {-tocopherol) }\end{array}$} \\
\hline & & & & $K_{232}$ & $K_{268}$ & \\
\hline Sample & $6.3 \pm 0.3^{\mathrm{b}}$ & $5.1 \pm 0.1^{\mathrm{b}}$ & $0.55 \pm 0.00^{\mathrm{c}}$ & $1.82 \pm 0.00^{\mathrm{c}}$ & $0.22 \pm 0.00^{\mathrm{d}}$ & $288.63 \pm 59.78^{\mathrm{a}, \mathrm{b}}$ \\
\hline
\end{tabular}

All analyses were performed in duplicate. The different letters mean significant differences $(p<0.05)$ among results. The letters are $a, b$, $\mathrm{c}$ and $\mathrm{d}$ according to the decrease in the result values.

the use of high quality raw material for the preparation of cold-pressed peanut oil.

\subsection{Vitamin-E-active compounds}

The fatty acid profile of the oil is not the only indicator for the identity and quality of an oil. Vitamin-E-active compounds such as tocopherols and tocotrienols are very important minor compounds responsible for the oxidative stability of the oil and its antioxidant activity.

Table 3 shows almost equal amounts of $\alpha$ and $\gamma$ tocopherols $\left(14.38 \pm 0.20\right.$ and $14.51 \pm 0.20 \mathrm{mg} \cdot 100 \mathrm{~g} \mathrm{~g}^{-1}$ of oil, respectively). The total level of Vitamin-Eactive compounds in Macedonian peanut oil was similar to the results published by Jonnala et al. According to their findings, the peanut oil from the variety "Tamrun 96" had the highest tocopherol content with $32.2 \mathrm{mg} \cdot 100 \mathrm{~g}^{-1}$ oil (Jonnala et al., 2006). Macedonian peanut oil from the "Virginia" variety had $29.56 \pm 0.4 \mathrm{mg} \cdot 100 \mathrm{~g}^{-1}$ of oil of total VitaminE-active compounds. The levels of $\beta$-tocotienol $\left(0.35 \pm 0.00 \mathrm{mg} \cdot \mathrm{kg}^{-1}\right.$ of oil $)$ and $\delta$-tocopherol $\left(0.31 \pm 0.00 \mathrm{mg} \cdot \mathrm{kg}^{-1}\right.$ of oil) were in good agreement with the published results of Carrín and Carelli (Carrín and Carelli, 2010).

\subsection{Antioxidant activity by DPPH assay}

Oxidative stability and antioxidant activity are two parameters which explain the resistance of oils against oxidative deterioration by oxygen during heating and storage. Antioxidant effectiveness of oil is dependent on the extent to which the antioxidant participates in side reactions, such reactions with species other than peroxyl radicals. These side reactions will decrease the level of antioxidant active compounds such as tocopherols, phytosterols and phenolic compounds and lead to the formation of active radicals able to initiate new oxidation reaction chains.
Statements in our work are very similar to those made by Tuberoso et al. (2007); Kostadinović Veličkovska and Mitrev (2013) and Kostadinović Veličkovska et al. (2015) who concluded that free radical scavenging was mainly influenced by the tocopherol content and polyunsaturated fatty acids in oil.

\subsection{Sterol composition in oils}

Pytosterols are minor usaponifiable compounds which are predominant in cold-pressed oils and almost absent in refined oils. Their presence in the oils is frequently connected to higher antioxidant activity (Grosso et al., 1997). The published results for the total level of pytosterols in peanut oil were in the range of $900-4344 \mathrm{mg} \cdot \mathrm{kg}^{-1}$ of oil (Carrín and Carelli, 2010).

Table 4 shows the level of particular phyrosterols as well as the total content of phytosterols in peanut oil $\left(2658.59 \pm 74.82 \mathrm{mg} \cdot \mathrm{kg}^{-1}\right.$ of oil). $\beta$-sitosterol was the major phytosterol with amounts of $1812.21 \pm 22.17 \mathrm{mg} \cdot \mathrm{kg}^{-1}$ oil. Champesterol was the second, most dominant phytosterol in cold-pressed peanut oil with a level of $320.55 \pm 17.07 \mathrm{mg} \cdot \mathrm{kg}^{-1}$ oil. $\Delta 5$-avenasterol was found to be the third most abundant sterol with a level of $236.16 \pm 14.18 \mathrm{mg} \cdot \mathrm{kg}^{-1}$ oil. It was found that $\Delta 5$-avenasterol has an antipolymerization effect, which could protect the oil from oxidation during prolonged heating at high temperatures. The significant oxidative stability of cold-pressed peanut oil can be attributed to the presence of higher levels of this phytosterol apart from the fatty acid profile and vitamin-E-related compounds in the oil. Stigmasterol was present in the amount of $133.12 \pm 12.51 \mathrm{mg} \cdot \mathrm{kg}^{-1}$ oil and all other phytosterols were present in amounts bellow $35 \mathrm{mg} \cdot \mathrm{kg}^{-1}$ oil. The results of the phytosterol composition obtained from Macedonian peanut oil from "Virginia" variety were in good agreement with the results of Grosso et al. (1997). According to their findings, $\beta$-sitosterol was detected at levels of 55.3 to

TABLE 3. Vitamin-E-active compounds in cold-pressed oils ( $\mathrm{mg} \cdot 100 \mathrm{~g}^{-1}$ of oil). HPLC analyses were performed in duplicate

\begin{tabular}{|c|c|c|c|c|c|}
\hline & $\alpha$-tocopherol & $\gamma$-tocopherol & $\beta$-tocotrienol & $\delta$-tocopherol & Total \\
\hline Cold- pressed peanut oil & $14.39 \pm 0.2^{\mathrm{a}}$ & $14.51 \pm 0.2^{\mathrm{a}}$ & $0.35 \pm 0.0^{\mathrm{b}}$ & $0.31 \pm 0.0^{\mathrm{b}}$ & $29.56 \pm 0.4$ \\
\hline
\end{tabular}

HPLC analyses were performed in duplicate. The different letters mean significant differences $(\mathrm{p}<0.05)$ among results. The letters are $a$ and $b$ according to the decrease in the result values. 
TABLE 4. Determination of the content of pytosterols $\left(\mathrm{mg} \cdot \mathrm{kg}^{-1}\right)$

\begin{tabular}{|c|c|}
\hline \multicolumn{2}{|c|}{ Phytosterols in cold pressed peanut oil } \\
\hline Cholesterol & $3.78 \pm 0.25^{\mathrm{i}}$ \\
\hline Brassicasterol & $7.99 \pm 0.09^{\mathrm{h}}$ \\
\hline 24-Methylencholesterol & $14.55 \pm 0.02^{\mathrm{g}}$ \\
\hline Campesterol & $320.55 \pm 17.07^{b}$ \\
\hline Campestanol & $32.55 \pm 1.72^{\mathrm{e}}$ \\
\hline Stigmasterol & $133.12 \pm 12.51^{\mathrm{d}}$ \\
\hline$\Delta 7$-Campestanol & $5.78 \pm 0.59^{\mathrm{g}}$ \\
\hline$\Delta 5,23$-Stigmastadienol & $0.81 \pm 0.01^{\mathrm{j}}$ \\
\hline Chlerosterol & $13.81 \pm 0.11^{\mathrm{g}}$ \\
\hline B-Sitosterol & $1812.21 \pm 22.17^{\mathrm{a}}$ \\
\hline Sitostanol & $29.88 \pm 1.33^{\mathrm{e}}$ \\
\hline$\Delta 5$-Avenasterol & $236.16 \pm 14.18^{c}$ \\
\hline$\Delta 5,24$-Stigmastadienol & $14.52 \pm 1.28^{\mathrm{g}}$ \\
\hline$\Delta 7$-Stigmastenol & $8.63 \pm 1.07^{\mathrm{h}}$ \\
\hline$\Delta 7$-Avenasterol & $24.25 \pm 2.52^{\mathrm{f}}$ \\
\hline Total & $2658.59 \pm 74.82$ \\
\hline
\end{tabular}

GC analyses were performed in duplicate. The different letters mean significant differences $(\mathrm{p}<0.05)$ among results. The letters are $\mathrm{a}, \mathrm{b}, \mathrm{c}, \mathrm{d}, \mathrm{e}, \mathrm{f}, \mathrm{g}, \mathrm{h}$ and $\mathrm{i}$ according to the decrease in the result values.

$61.6 \%$ from the total phytosterols in all peanut varieties. The abundance of $\beta$-sitosterol in Macedonian peanut oil was $68.16 \%$ from the total phytosterol content. Campesterol was present from 13.7 to $17.2 \%$ in the samples from Bolivia and Argentina. The content of campesterol in Macedonian peanut oil was $12.06 \%$. However, Macedonian peanut oil from the "Virginia" variety consists of almost double the quantity of $\Delta 5$-avenasterol in comparison to stigmasterol. In the samples of peanut oil from Bolivia and Argentina almost equal contents of both phytosterols were detected (Grosso et al., 1997).

\section{CONCLUSIONS}

Cold-pressed peanut oil obtained from organically produced peanuts from the Macedonian "Virginia" variety was investigated for the first time. The analytical methods presented in this study can be used for fast and accurate chemical characterization of major and minor constituents present in vegetable oils.

Results from this study show that the most important class of compounds responsible for the antioxidant activity of peanut oil measured by the DPPH assay was Vitamin-E-active compounds. Almost equal amounts of $\alpha$ and $\gamma$-tocopherol indicated peanut oil as a valuable source of Vitamin-E-active compounds with a total amount of $29.56 \pm 0.4 \mathrm{mg} \cdot 100 \mathrm{~g}^{-1}$ oil. Phytosterols are the second most important class of compounds which can participate in the antioxidant potential of the oil. Apart from $\beta$-sitosterol as the most abundant phytosterol $\left(1812.21 \pm 22.17 \mathrm{mg} \cdot \mathrm{kg}^{-1}\right.$ oil), the other three phytosterols, $\Delta 5$-avenasterol (236.16 $\pm 14.18 \mathrm{mg} \cdot \mathrm{kg}^{-1}$ oil), champesterol (320.55 $17.07 \mathrm{mg} \cdot \mathrm{kg}^{-1}$ oil), and stigmasterol (133.12 \pm 12.51 $\mathrm{mg} \cdot \mathrm{kg}^{-1}$ oil) can contribute to the antioxidant potential of the oil. However, the antioxidant assay indicated Vitamin-E-active compounds as the most active against the DPPH radical. Finally, oxidative stability is strongly influenced by the degree of unsaturation of fatty acids as well as the effect of roasting.

\section{ACKNOWLEDGMENTS}

Financial support from Deutscher Akademischer Austausch Dienst (DAAD) for Sanja Kostadinović Veličkovska as a participant in the SOE-DAAD project "Catalyst for South Eastern Europe MatCatNet" is gratefully acknowledged. Augustin C. Mot from Babes-Bolyai University, Cluj-Napoca is acknowledged for his scientific advice.

\section{REFERENCES}

Ahmed EH, Young CT. 1982. Composition, nutrition and flavor of peanut. In: Pattee HE, Young CT (Eds.) Peanut Science and Technology, American Peanut Research and Education Society, Inc., Yoakum, 655-687.

Brown DF, Cater CM, Mattil KF, Darroch JA. 1975. Effect of variety, growing location and their interaction on the fatty acid composition of peanuts. J. Food Sci. 40, 1055-1060. http://dx.doi.org/10.1111/j.1365-2621.1975.tb02266.x.

Carrín ME, Carelli AA. 2010. Peanut oil: Compositional data. Eur. J. Lipid Sci. Tech. 112, 697-707. http://dx.doi.org/10.1002/ ejlt.200900176.

Chetschik I, Granvogl M, Schieberle P. 2010. Quantitation of Key Peanut Aroma Compounds in Raw Peanuts and Pan-Roasted Peanut Meal. Aroma Reconstitution and Comparison with Commercial Peanut Products. J. Agric. Food Chem. 58, 11018-11026. http://dx.doi.org/10.1021/ jf1026636.

Durmaz G, Karabulut I, Topḉu A, Asiltürk M, Kutlu T. 2010. Roasting-Related Changes in Oxidative Stability and Antioxidant Capacity of Apricot Kernel Oil. J. Am. Oil Chem. Soc. 87, 401-409. http://dx.doi.org/10.1007/s11746009-1518-9.

Grosso NR, Lucini EI, Lopez AG, Guzmán CA. 1999. Chemical composition of aboriginal peanut (Arachis hypogaea $\mathrm{L}$ ) seeds from Uruguay. Grasas Aceites, 50, 203-207. http:// dx.doi.org/10.3989/gya.1999.v50.i3.657.

Grosso NR, Nepote V, Guzmán CA. 2000. Chemical composition of some wild peanut species (Arachis) seeds. $J$. Agric. Food Chem. 48, 806-809. http://dx.doi.org/10.1021/ jf9901744.

Grosso NR, Zygadlo JA, Burroni LV, Guzmán CA. 1997. Fatty acid, sterol and proximate compositions of peanut species (Arachis L.) seeds from Bolivia and Argentina. Grasas Aceites, 48, 219-225. http://dx.doi.org/10.3989/gya.1997. v48.i4.792.

Grosso NR, Zygadlo JA, Lamarque AL, Maestri DM, Guzmán CA. 1997. Proximate, fatty acid and sterol compositions of aboriginal peanut (Arachis hypogaea L) seeds from Bolivia. J. Sci. Food Agric. 73, 349-356.

Jonnala RS, Dunford NT, Kelly C. 2006. Tocopherol, phytosterol and phospholipid compositions of genetically modified peanut varieties. J. Sci. Food Agric. 86, 473-476. http:// dx.doi.org/10.1002/jsfa.2372.

Kostadinović S, Wilkens A, Stefova M, Ivanova V, Vojnoski B, Mirhosseini H, Winterhalter P. 2012. Stilbene levels and 
antioxidant activity of Vranec and Merlot wines from Macedonia: Effect of variety and enological practices. Food Chem. 135, 3003-3009. http://dx.doi.org/10.1016/j. foodchem.2012.06.118.

Kostadinović Veličkovska S, Brühl L, Mitrev S, Mirhosseini H, Matthäus B. 2015. Quality evaluation of cold-pressed edible oils from Macedonia, Eur. J. Lipid Sci. Technol. 117. Article in press. http://dx.doi.org/10.1002/ejlt.201400623.

Kostadinović Veličkovska S, Mitrev S. 2013. Characterization of fatty acid profile, polyphenolic content and antioxidant activity of cold pressed and refined edible oils from Macedonia. J. Food Chem. Nutr. 1, 16-21.

Lopes RM, Agostini-Costa TS, Gimenes MA, Silveira D. 2011. Chemical composition and biological activities of Arachis Species. J. Agric. Food Chem. 59, 4321-4330. http://dx.doi. org/10.1021/jf104663z.

O'Keefe SF, Wiley VA, Knauft DA. 1993. Comparison of oxidative stability of high- and normal-oleic peanut oils. J. Am. Oil Chem. Soc. 70, 489-492. http://dx.doi.org/10.1007/ BF02542581.

Özcan M, Seven S. 2003. Physical and chemical analysis and fatty acid composition of peanut, peanut oil and peanut butter from COM and NC-7 cultivars. Grasas Aceites, 54, 12-18. http://dx.doi.org/10.3989/gya.2003.v54.i1.270.

Sullivan TAO, Ambrosini GL, Mori TA, Beilin LJ, Oddy WH.

2011. Omega-3 index correlates with reduced cardiovascular disease risk factors in adolescent boys. Lipids, 46, 59-67. http://dx.doi.org/10.1007/s11745-010-3499-8.

Tuberoso CIG, Kowalczyk A, Sarritzu E, Cabras P. 2007. Determination of antioxidant compounds and antioxidant activity in commercial oilseeds for food use. Food Chem. 103,1494-1501. http://dx.doi.org/10.1016/j.foodchem.2006. 08.014 .

Varney ME, Buchanan JT, Dementieva Y, Hardman WE, Sollars VE. 2011. A high Omega-3 fatty acid diet has different effects on early and late stage myeloid progenitors. Lipids, 46, 47-57. http://dx.doi.org/10.1007/s11745-010-3491-3.

Veldsink JW, Muuse BG, Meijer MM, Petrus Cuperus TF, Van de Sande RL, Van Putte KM. 1999. Heat pretreatment of oilseeds: effect on oil quality. Fett/Lipid, 101, 244-248.

Zock PL, De Varies JHM, De Fouw NJ, Katan MB. 1995. Positional distribution of fatty acids in dietary triglycerides: effect of fasting blood lipoprotein concentration in humans. Am. J. Clin. Nutr. 61, 48-55. 